\title{
Analisis Pemahaman Operasi Bentuk Aljabar Siswa SMP Berdasarkan Level Kecerdasan Emosional
}

\author{
Putri Ariningtyas $^{1}$, Subanji ${ }^{2}$, I Nengah Parta ${ }^{3}$ \\ 1, 2, 3 Pascasarjana Pendidikan Matematika, Fakultas Matematika dan Ilmu Pengetahuan Alam, Universitas Negeri Malang, \\ Jl. Semarang No 5, Malang, Jawa Timur, Indonesia \\ putryarin59@gmail.com
}

\begin{abstract}
This study aims to describe the insight of operations algebraic expressions junior high school students based on the level of emotional intelligence. Descriptive research using purposive sampling as the subject was carried out at SMPN 1 Malang on 30 students of class VII-H. To describe qualitatively, 3 students were taken from high, medium, and low emotional intelligence levels. Instruments used are emotional intelligence questionnaires and test sheets. High emotional intelligence level students have very good understanding of algebraic expressions, medium emotional intelligence level students have a good understanding but have not been able to perform operations on algebraic expressions, while low emotional intelligence students have poor understanding because they have not been able to restate and present concepts, and algebraic operations.
\end{abstract}

Keywords: Insight, Operations algebraic expressions, Emotional intelligence

\begin{abstract}
Abstrak
Penelitian ini bertujuan mendeskripsikan pemahaman operasi bentuk aljabar siswa SMP berdasarkan level kecerdasan emosional. Penelitian deskriptif dengan teknik pengambilan subjek purposive sampling dilaksanakan di SMPN 1 Malang pada 30 siswa kelas VII-H. Instrumen yang digunakan angket kecerdasan emosional dan lembar tes. Untuk mendeskripsikan secara kualitatif maka diambil tiga siswa yang diambil berdasarkan pengisian angket kecerdasan emosional, hasil pengerjaan tes serta rekomendasi guru. Pemahaman konseptual dan prosedural siswa tiap level yaitu, siswa level kecerdasan emosional tinggi memiliki pemahaman bentuk aljabar baik, siswa level kecerdasan emosional sedang memiliki pemahaman cukup baik tetapi belum mampu melakukan operasi bentuk aljabar, sedangkan siswa kecerdasan emosional rendah memiliki pemahaman kurang baik karna belum mampu menyatakan ulang konsep, serta melakukan operasi bentuk aljabar.
\end{abstract}

Kata kunci: Pemahaman, Operasi Bentuk Aljabar, Kecerdasan Emosional

Copyright (c) 2021 Putri Ariningtyas, Subanji, I Nengah Parta

$\triangle$ Corresponding author: Putri Ariningtyas

Email Address: putryarin59@gmail.com (Jalan Pulosari 1 Blok O/8, Malang)

Received 15 July 2021, Accepted 26 July 2021, Published 07 August 2021

\section{PENDAHULUAN}

Matematika merupakan salah satu ilmu pengetahuan yang berperan dalam pengembangan proses pendidikan. Selain itu menurut (Laurens, Batlolona, Batlolona, \& Leasa, 2018) matematika telah menjadi modal dasar bagi kehidupan, khususnya untuk memecahkan masalah sehari-hari. Matematika sudah menjadi mata pelajaran dasar pada setiap jenjang pendidikan formal, untuk itu siswa diharapkan memiliki berbagai kemampuan agar dapat meningkatkan kualitas pembelajaran. Lebih lanjut, salah satu tuntutan siswa dalam kurikulum adalah siswa dapat memahami konsep matematika, menjelaskan keterkaitan antarkonsep dan mengaplikasikan konsep atau algoritma, secara luwes, akurat, efisien, serta tepat, dalam pemecahan masalah (Kamarullah, 2017).

Melalui pembelajaran matematika diharapkan siswa memiliki kemampuan prosedural dan konseptual. (Lestari \& Surya, 2017) menyatakan kemampuan pemahaman merupakan kemampuan utama harus dimiliki oleh siswa terlebih dahulu, sebelum memiliki kemampuan lain seperti kemampuan pemecahan masalah, kemampuan komunikasi, dan kemampuan representasi matematis. Pengetahuan yang 
dipelajari dengan pemahaman memberikan dasar dalam pembentukan pengetahuan baru lalu dapat digunakan memecahkan masalah-masalah baru, setelah terbentuknya pemahaman dari suatu konsep, siswa dapat menyampaikan pendapat serta menjelaskan sebuah konsep (Masitoh \& Prabawanto, 2016). Lebih lanjut, (Suratman, 2011) menyatakan saat siswa memperoleh pemahaman konseptual dalam bidang matematika, maka siswa mampu melihat hubungan antara konsep dan prosedur sehingga dapat memberikan argumen untuk menjelaskan mengapa beberapa fakta merupakan akibat dari fakta yang lain. Dalam penelitian (Betyka, Putra, \& Erita, 2019) mengembangkan kemampuan memahami konsep siswa adalah salah satu tujuan utama pembelajaran matematika di sekolah

Pemahaman siswa juga dapat terbentuk dari sikap siswa saat pembelajaran berlangsung. Hal ini selajan dengan pendapat (Nadeak, 2020) menyatakan bahwa peserta didik yang memiliki motivasi dan sikap positif tinggi akan semangat serta memperhatikan penjelasan guru ketika pembelajaran berlangsung. Sikap positif dan motivasi yang ada pada siswa berhubungan dengan kecerdasan emosional. (Singh, Verma, \& Singh, 2013) mengungkapkan kecerdasan emosional adalah kemampuan meliputi kemampuan untuk mengendalikan diri, memiliki daya tahan menghadapi sesuatu dan mampu mengatur suasana hatinya. Sejalan dengan (Chamundeswari, 2013) karena kecerdasan emosional adalah bakat utama, kapasitas yang sangat mempengaruhi semua kemampuan lain dalam kegiatan pembelajaran pembelajaran. Goleman menambahkan bahwa para ahli psikologi sepakat kecerdasan intelektual (IQ) hanya mendukung sekitar 20\% faktor yang menentukan keberhasilan belajar siswa, sedangkan $80 \%$ sisanya berasal dari faktor lain termasuk kecerdasan emosional (EQ). Pada proses belajar mengajar, kecerdasan emosional harus diterapkan untuk keberhasilan belajar siswa untuk masa kini dan masa yang akan datang (Islami, Putra, Deswita, \& Rusliah, 2020). Penelitian psikologi terbaru menunjukkan kecerdasan emosional mempengaruhi keberhasilan belajar termasuk pemahaman (Marhaeni, 2016).

Ruang lingkup mata pelajaran matematika SMP meliputi aspek bilangan, aljabar, geometri dan pengukuran, serta statistika dan peluang. Berdasarkan Silabus Permendikbud no 14 Tahun 2019 materi pembelajaran aljabar meliputi, bentuk aljabar dan unsur - unsurnya, operasi hitung bentuk aljabar dan penyederhanaan bentuk aljabar. Hasil observasi awal yang ditemukan peneliti di SMPN 1 Malang, pemahaman konsep siswa masih rendah. Kondisi ini ditunjukkan dengan data ulangan harian yang diikuti oleh 30 siswa, ternyata rata-rata hanya 22,23\% siswa yang mampu mencapai Kriteria Ketuntasan Minimal (KKM) yaitu 75. Banyak faktor yang menyebabkan rendahnya pemahaman konsep siswa. (Planinic, MilinSipus, Katic, Susac, \& Ivanjek, 2012) berpendapat penyebab rendahnya pemaham konsep karna cara belajar siswa yang masih cenderung menghafal, materi pelajaran yang diajarkan memiliki konsep mengambang sehingga siswa tidak menemukan kunci materi yang dipelajari, dan tenaga pengajar kurang berhasil menyampaikan materi. Pada observasi awal ditemukan siswa cenderung melakukan operasi suku tak sejenis, seperti menyederhanakan suatu bentuk aljabar binomial dengan mengurangi kedua suku contoh $6 x-3=3 x$. Hal ini mengindikasikan bahwa masih ada permasalahan perihal pemahaman prosedural siswa. Selain itu ditemukan permasalahan terkait pemahaman konseptual, siswa masih menganggap variabel hanya merepresentasikan nilai atau bilangan tertentu saja bukan sebagai generalisasi anggota suatu 
Analisis Pemahaman Operasi Bentuk Aljabar Siswa SMP Berdasarkan Level Kecerdasan Emosional, Putri Ariningtyas,

himpunan bilangan.

Penelitian yang dilakukan oleh (Kurniawan, Mulyati, \& Rahardjo, 2017) siswa tidak dapat menerapkan rumus dalam perhitungan sederhana, mengaitkan satu konsep dengan konsep bentuk aljabar, sehingga siswa kesulitan dalam menyelesaikan soal serta gugup dalam menjawab pertanyaan tentang materi matematika yang kurang dipahami. Sifat gugup dan kurang percaya diri siswa berkaitan dengan rendahnya kecerdasan emosional hal yang berakibat siswa menghindari untuk memahami materi matematika yang dianggap sulit (Farhan \& Alfin, 2019). Sejalan dengan (Apriani, Buyung, \& Relawati, 2017) siswa tidak memperoleh pemahaman tentang aspek struktural aljabar sehingga siswa berusaha menghafal aturan dan prosedur. Kecerdasan emosional adalah salah satu faktor yang dapat mempengaruhi kemampuan pemahaman siswa (Pangastuti, Johan, \& Kurniasari, 2014).

Pentingnya pendidik untuk mengetahui bagaimana pemahaman siswa mengenai bentuk aljabar, baik itu pemahaman konseptual dan pemahaman prosedural. Sehingga guru dapat merencanakan suatu pembelajaran yang mampu mengoptimalkan pemahaman siswa dengan berbagai macam tingkat kecerdasan emosional siswa. Berdasarkan latar belakang yang telah dipaparkan, perlu adanya penelitian lebih lanjut mengenai bagaimana pemahaman materi bentuk aljabar siswa SMP kelas VII berdasarkan level kecerdasan emosional. Mengatahui kemampuan pemahaman siswa dalam proses pembelajaran merupakan salah satu indikator penting untuk mencapai keberhasilan belajar (Dewi \& Ibrahim, 2019).

\section{METODE}

Penelitian ini merupakan penelitian deskriptif dengan teknik pengambilan subjek purposive sampling yaitu dengan memperhatikan level kecerdasan emosional. Penelitian dilakukan kepada 30 siswa kelas VII$\mathrm{H}$ di SMPN 1 Malang dengan diberikan angket kecerdasan emosional dan lembar tes. Subjek dipilih berdasarkan hasil level kecerdasan emosional, rekomendasi guru dan mampu menyelesaikan seluruh tes yang diberikan. Angket kecerdasan emosional disusun berdasarkan teori Goleman pada tingkat usia kelas VII SMP. Angket disusun menggunakan skala likert yang terdiri dari tiga aspek dalam kecerdasan emosional yang mempengaruhi pemahaman konsep antara lain: Mengenali emosi diri (self awereness), dimana siswa dapat mengenali emosi diri sendiri dan mengetahui penyebab timbulnya emosi; mengelola emosi (self regulation), dimana siswa mampu mengendalikan emosi diri; dan Memotivasi diri sendiri (motivation), siswa memiliki dorongan untuk berprestasi dan memilki sikap optimis.

Pemahaman bentuk aljabar yang dimaksud dalam penelitian ini adalah pemahaman konseptual dan prosedural. Indikator yang digunakan untuk menganalisis hasil pekerjaan subjek adalah (1) mampu menyatakan ulang konsep bentuk aljabar, (2) mampu mengaplikasikan konsep untuk menyelesaikan masalah, (3) mampu menyajikan konsep dalam bentuk representasi matematis, dan (4) mampu menyelesaiakan operasi bentuk aljabar. Setelah menganalisis hasil pekerjaan subjek wawancara semi terstruktur dilakukan untuk mendapatkan informasi yang mendukung hasil penelitian. Gambar 1 menyajikan cuplikan soal tes penelitian, soal nomor 1 mengenai contoh dan bukan contoh bentuk aljabar dan soal nomor 2 mengenai menyelesaikan masalah nyata dalam bentuk aljabar. 


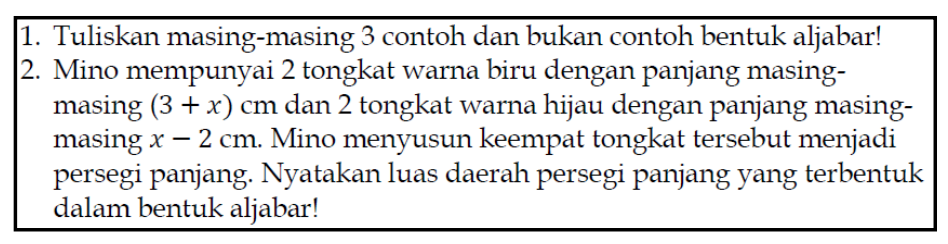

\section{Gambar 1. Cuplikan Soal Tes}

Hasil tes kemudian dianalisis dengan menggunkakan rubrik analitik skala 4. Rubrik analitik ialah pedoman untuk menilai berdasar beberapa kriteria yang ditentukan (Handayani, Hartatiana, \& Muslimahayati, 2020). Untuk mengetahui kategori kemampuan pemahaman siswa digunakan acuan berikut yang merupakan modifikasi dari penelitian yang dilakukan (Zebua, 2020), nilai siswa diperoleh dengan menggunakan rumus: Nilai siswa $=\frac{\text { skor yang diperoleh siswa }}{(\text { skor total }) \times 100}$, dan Tabel 2 yang menunjukan kategori hasil penilaian pemahaman materi bentuk aljabar siswa.

Tabel 1. Kategori Pemahaman

\begin{tabular}{|c|c|}
\hline Kategori & Nilai Siswa \\
\hline Sangat Baik & $85<$ Nilai Siswa $\leq 100$ \\
\hline Baik & $70<$ Nilai Siswa $\leq 85$ \\
\hline Cukup Baik & $55<$ Nilai Siswa $\leq 70$ \\
\hline Kurang Baik & $0<$ Nilai Siswa $\leq 55$ \\
\hline
\end{tabular}

\section{HASIL DAN DISKUSI}

Kemampuan pemahaman siswa diambil dari hasil tes yang dilakukan pada 30 siswa kelas VII-H dilanjutkan dengan pemberian angket kecerdasan emosional siswa. Hasil pekerjaan siswa ditelaah lalu dikategorikan berdasarkan nilai yang diperoleh, Tabel 3 menunjukan rekapitulasi kemampuan pemahaman siswa materi bentuk aljabar kelas tersebut dan Tabel 4 tingkat kecerdasan emosional siswa.

Tabel 2. Rekapitulasi Kemampuan

\begin{tabular}{|c|c|}
\hline Kategori & Jumlah Siswa \\
\hline Sangat Baik & 3 \\
\hline Baik & 6 \\
\hline Cukup Baik & 11 \\
\hline Kurang Baik & 10 \\
\hline
\end{tabular}

Tabel 3. Tingkat Kecerdasan Emosional Siswa

\begin{tabular}{|c|c|}
\hline Level & Jumlah Siswa \\
\hline Tinggi & 3 \\
\hline Sedang & 15 \\
\hline Rendah & 12 \\
\hline
\end{tabular}

Berdasarkan soal tes dan angket kecerdasan emosional yang telah diberikan kepada 30 siswa, dipilih 3 subjek yang mewakili setiap level kecerdasan emosional yaitu subjek level kecerdasan emosional tinggi (T1), subjek level kecerdasan emosional sedang (S1), dan subjek level kecerdasan emosional rendah (R1) 
untuk dideskripsikan secara kualitatif. Subjek dipilih berdasarkan hasil level kecerdasan emosional, rekomendasi guru dan mampu menyelesaikan seluruh tes yang diberikan. Data kualitatif didapatkan dari analisis hasil pekerjaan siswa dan wawancara semi terstruktur

\section{Pemahaman Bentuk Aljabar Pada Siswa Level Kecerdasan Emosional Tinggi(T1)}

Gambar 2 di bawah menyajikan hasil pekerjaan subjek T1 dalam menyelesaikan soal nomor 1.
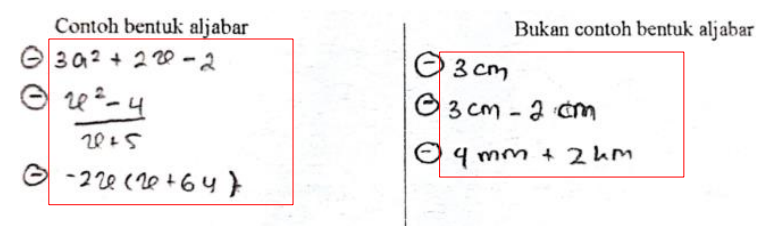

Gambar 2. Subjek T1 menuliskan contoh dan bukan contoh bentuk aljabar

Subjek T1 mampu memenuhi menuliskan contoh dan bukan contoh bentuk aljabar serta menjelaskan alasan dengan bahasa sendiri, hal ini didukung dari cuplikan wawancara berikut.

Peneliti : Bisakah kamu menjelaskan jawaban yang kamu tuliskan?

T1 : Menurut saya contoh bentuk aljabar itu mempunyai unsur bentuk aljabar seperti koefisien variabel, konstanta dan suku sehingga yang tidak terdapat unsur tersebut bukan bentuk aljabar.

Subjek T1 hanya menjelaskan contoh bentuk aljabar adalah jika terdapat koefisien, variabel, suku dan konstanta yang mana merupakan unsur bentuk aljabar. Sehingga untuk bukan contoh bentuk aljabar T1 menuliskan operasi hitung satuan panjang karna menurutnya contoh tersebut tidak mengandung unsur bentuk aljabar. Berdasarkan hal tersebut terlihat bahwa pemahaman siswa masih semu, karena hanya terpatok pada koefisien, variabel, dan konstanta sebagai ciri bentuk aljabar. Berikut Gambar 3 hasil pekerjaan T1 dalam mencari luas pada soal nomor 2 .

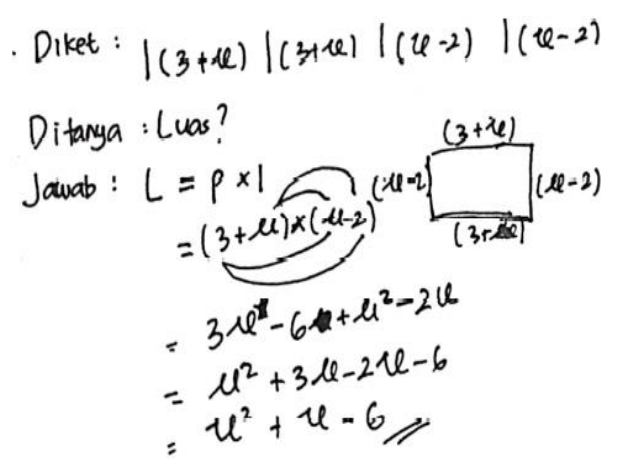

Gambar 3. Hasil Pekerjaan Subjek T1

Untuk menyelesaikan soal no 2, subjek T1 menuliskan informasi pada soal, seperti yang diketahui dan ditanyakan. Selanjutnya, subjek T1 mengambarkan sketsa persegipanjang untuk membantu menuliskan model matematika sesuai dengan konsep luas dengan benar. Berdasarkan model matematika dibuat, subjek T1 melakukan perhitungan untuk mendapatkan hasil akhir. Saat melakukan perhitungan subjek T1 terlihat 
terburu-buru sehingga melakukan kesalahan penulisan tetapi, subjek menyadari dan langsung memperbaikinya. Hasil akhir yang diperoleh T1 sesuai dengan soal yang disajikan.

\section{Pemahaman Bentuk Aljabar Pada Siswa Level Kecerdasan Emosional Tinggi (S1)}

Gambar 2 di bawah menyajikan hasil pekerjaan subjek S1 dalam menyelesaikan soal nomor 1.

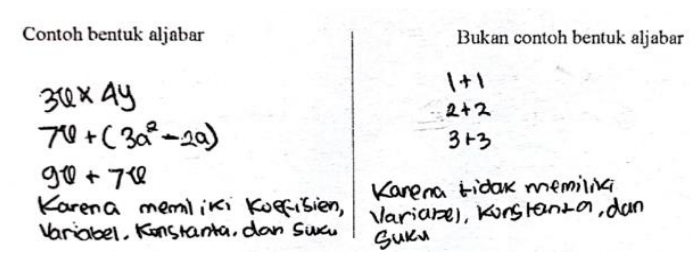

Gambar 4. Subjek S1 menuliskan contoh dan bukan contoh bentuk aljabar serta alasan

Subjek S1 mampu memenuhi menuliskan contoh dan bukan contoh bentuk aljabar serta menjelaskan alasan dengan bahasa sendiri, hal ini didukung dari cuplikan wawancara berikut.

Peneliti : Bisakah kamu menjelaskan jawaban yang kamu tuliskan?

S1 : Menurut saya contoh bentuk aljabar itu mempunyai koefisien variabel, konstanta dan suku sehingga yang bukan contoh tidak ada.

Subjek S1 menjelaskan contoh bentuk aljabar adalah jika terdapat koefisien, variabel, suku dan konstanta yang mana merupakan unsur bentuk aljabar. Sehingga untuk bukan contoh bentuk aljabar S1 menuliskan operasi hitung penjumlahan yang tidak memiliki unsur bentuk aljabar. Salah satu unsur bentuk aljabar adalah terdapat suku, subjek S1 mengklaim operasi penjumlahan yang dituliskan tidak memiliki suku. Dari penjelasan di atas, subjek S1 mampu menjelaskan contoh bentuk aljabar dengan tepat tetapi untuk bukan contoh aljabar alasan yang diberikan kurang sesuai. Berikut Gambar 5 hasil pekerjaan S1 dalam mencari luas pada soal nomor 2 .

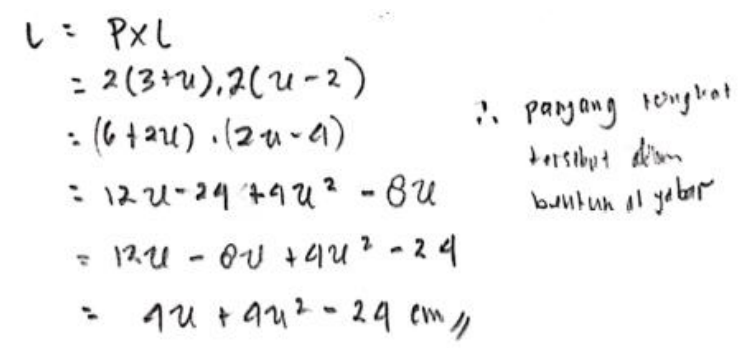

Gambar 5. Hasil pekerjaan S1

Untuk menyelesaikan soal nomor 2, subjek S1 menuliskan informasi yang ada pada soal dengan menggambarkan keempat tongkat beserta keterangan ukurannya. Subjek S1 dapat membuat model matematika tetapi tidak sesuai dengan soal yang disajikan yaitu terjadi kesalahan dalam menentukan rumus luas persegi panjang. Sehingga subjek S1 tidak mampu memperoleh hasil akhir yang sesuai dengan soal yang disajikan. 


\section{Pemahaman Bentuk Aljabar Pada Siswa Level Kecerdasan Emosional Tinggi (R1)}

Gambar 6 di bawah menyajikan hasil pekerjaan subjek R1 pada soal nomor 1

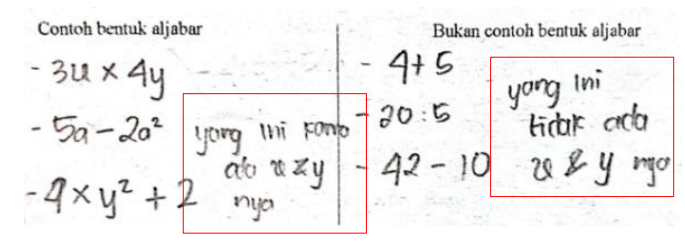

Gambar 6. Subjek S1 menuliskan contoh dan bukan contoh bentuk aljabar

Subjek R1 dapat menuliskan contoh dan bukan contoh bentuk aljabar, tetapi tidak dapat menjelaskan alasan menuliskan jawaban tersebut. Informasi ini didapatkan dari cuplikan wawancara yang dilakukan peneliti dengan subjek R1 berikut.

Peneliti : Bisakah kamu menjelaskan jawaban yang kamu tuliskan?

R1 : Biasanya contoh yang diberikan guru saya ada unsur $x$ atau $y$ nya kalau misal menuliskan bentuk aljabar.

Peneliti : Kira - kira apakah kamu mengetahui makna unsur x atau $y$ ?

R1 : Tidak, saya cuman tau kalau ada huruf x atau y atau z nya itu berarti contoh bentuk aljabar, selain tidak ada huruf itu bukan contoh bentuk aljabar.

Subjek R1 menyatakan bahwa tidak memahami makna simbol x, y, z pada bentuk aljabar dan hanya terpatok pada simbol x, y, z sebagai ciri bentuk aljabar. Berdasarkan tersebut, peneliti menyimpulkan bahwa subjek R1 tidak memahami makna dari variabel. Lebih lanjut subjek R1 tidak dapat menyebutkan unsurunsur bentuk aljabar. Selanjutnya, berikut disajikan Gambar 7 hasil pekerjaan subjek R1 pada soal nomor 2 menemukan luas.

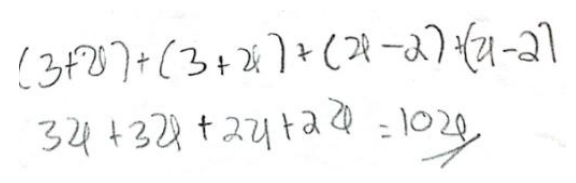

Gambar 5. Hasil Pekerjaan R1

Untuk hasil pekerjaan pada nomor 2, subjek R1 tidak dapat mendapatkan hasil akhir yang tepat dikarenakan salah membentuk model matematika sesuai dengan soal yang disajikan. Kemudian, saat melakukan operasi perhitungan subjek R1 melakukan kesalahan perhitungan dikarenakan kesulitan memahami makna variabel sehingga cenderung menggabungkan ekspresi aljabar menjadi jawaban tunggal. Penelitian yang dilakukan (Herutomo, 2017) mengungkapkan bahwa siswa kurang memahami konsep variabel sebagai sesuatu nilai yang belum diketahui dan beranggapan variabel hanya merepresentasikan nilai/bilangan tertentu saja.

Diskusi

Berikut disajikan Tabel 5 yang menunjukan pemahamam konsep dari tiap level kecerdasan emosional. 
Tabel 3. Tingkat Kecerdasan Emosional Siswa

\begin{tabular}{|c|c|c|c|}
\hline Level & Jumlah Siswa & Nilai Rata-Rata Siswa & Kategori Pemahaman \\
\hline Tinggi & 3 & 89,3 & Sangat Baik \\
\hline \multirow{2}{*}{ Sedang } & 6 & 83,3 & Baik \\
\cline { 2 - 4 } & 9 & 66,6 & Cukup Baik \\
\hline \multirow{2}{*}{ Rendah } & 2 & 58 & Cukup Baik \\
\cline { 2 - 4 } & 10 & 50 & Kurang Baik \\
\hline
\end{tabular}

Berdasarkan Tabel 5 di atas menunjukan bahwa untuk siswa dengan level kecerdasan emosional tinggi memiliki pemahaman yang sangat baik, selaras dengan (Labby, Lunenburg, \& Slate, 2012) individu dengan kecerdasan emosional tinggi ini memiliki kemampuan berpikir dan kritis. Siswa dengan kecerdasan emosional sedang ada yang memiliki pemahaman konseptual baik dan cukup baik, siswa sudah mampu menjelaskan konsep yang didapatkan dengan bahasa mereka sendiri tetapi masih ada kesalahan dalam mengaplikasikan konsep yang digunakan. Siswa dengan kecerdasan emosional sedang masih perlu mendapatkan bimbingan sehingga kemampuan akan setara dengan kecerdasan emosional tinggi (Bariyyah \& Latifah, 2019). Siswa dengan kecerdasan emosional rendah memiliki pemahaman konseptual cukup baik hingga kurang baik, hal ini disebabkan ketidakmampuan mengaplikasikan konsep dan kurang motivasi untuk belajar.

Bersumber dari ketiga hasil paparan pemahaman konsep tiap level kecerdasan emosional di atas, ditemukan bahwa untuk menuliskan contoh dan bukan contoh bentuk aljabar ketiga subjek dapat menuliskan jawaban dengan tepat, tetapi alasan tiap subjek beragam. Subjek T1 menjelaskan bahwa contoh bentuk aljabar terdiri dari unsur bentuk aljabar yaitu koefisien, variabel, konstanta, dan suku. Subjek S1 mengungkapkan jika bukan contoh aljabar jika tidak terdapat variable, kontanta, dan suku. Padahal jawaban yang subjek S1 tuliskan terdapat unsur suku, dari sini dapat disimpulkan bahwa subjek S1 belum memahami konsep suku. Kemudian, untuk subjek T1 tidak dapat menjelaskan penulisan contoh dan bukan contoh bentuk aljabar. Subjek T1 terpaku pada huruf $x, y$ dan $z$ yang dijelaskan guru di kelas tetapi tidak memahami makna huruf tersebut. Sejalan dengan penelitian (Limardani, Trapsilasiwi, \& Fatahillah, 2015) menunjukkan siswa masih mengalami kesulitan memahami makna suku, variabel, dan konstanta.

Untuk menyelesaikan masalah yang disajikan tentu perlu adanya pemahaman konseptual dan prosedural tersebut. (Febriyanti \& Novitasari, 2019) berpendapat pemahaman dan keterampilan yang dimiliki siswa diperlukan untuk menyelesaikan masalah. Pemahaman prosedural masing-masing subjek untuk menyelesaikan masalah pada nomor 2, hanya subjek T1 yang dapat mengaplikasikan rumus dengan tepat, membentuk model matematika sesuai soal, dan melakukan operasi hitung sehingga mendapatkan hasil akhir yang tepat. Untuk subjek S1 sudah dapat mengaplikasikan rumus sesuai soal yang disajikan, tetapi tidak sesuai dalam membentuk model matematika sehingga mendapatkan hasil akhir yang belum tepat walau subjek S1 dapat melakukan operasi hitung. Kemudian, subjek R1 tidak dapat mengaplikasikan rumus untuk menyelesaikan masalah, dapat membuat model matematika tetapi tidak sesuai dan tidak dapat melakukan operasi hitung bentuk aljabar karna mengalami kesulitan. (Zhao \& Schuchardt, 2021) 
Analisis Pemahaman Operasi Bentuk Aljabar Siswa SMP Berdasarkan Level Kecerdasan Emosional, Putri Ariningtyas,

mengungkapkan kesuiltan yang dialami siswa saat melakukan operasi yakni memahami makna variabel dan cenderung menggabungkan ekspresi aljabar menjadi jawaban tunggal. Pada penelitian (Kristanti, 2020) kesalahan dilakukan siswa dalam menyederhanakan bentuk aljabar karna tidak menggunakan sifat distribusi yang tidak tepat dalam operasi aljabar. Dengan demikian, dapat disimpulkan untuk kemapuan yang dimiliki yaitu mencakup kemampuan konseptual dan prosedural subjek T1 sangat baik, subjek S1 baik, serta subjek R1 masih kurang baik.

\section{KESIMPULAN}

Berdasarkan dari hasil penelitian dan pembahasan untuk pemahaman yang mencakup konseptual dan prosedural, kemampuan pemahaman siswa yang memiliki kecerdasan emosional tinggi sangat baik karna mampu memenuhi semua indikator pemahaman konsep. Pemahaman untuk siswa dengan kecerdasan emosional sedang adalah baik, siswa mampu menyatakan ulang konsep bentuk aljabar dan mengaplikasikan konsep untuk menyelesaikan masalah tetapi belum mampu menyajikan konsep dalam bentuk representasi matematis, dan menyelesaiakan operasi bentuk aljabar. Sedangkan, pemahaman siswa level kecerdasan emosional rendah masih kurang baik. Siswa masih belum tepat menyatakan ulang konsep bentuk aljabar, dan masih mengalami kesulitan dalam memahami makna variabel. Harapan hasil penelitian ini dapat digunakan sebagai masukan untuk guru sehingga akan menaruh perhatian lebih kepada siswa yang masih kurang dalam pemahaman konseptual dan prosedural materi operasi bentuk aljabar terutama pada hal yang menjadi sumber kesulitan.

\section{UCAPAN TERIMA KASIH}

Saya mengucapkan terima kasih kepada Mega Putri D. I, S.Pd selaku guru matematika SMP Negeri 1 Malang yang telah memberikan izin penelitian serta siswa-siswi kelas VII SMP Negeri 1 Malang yang telah memberikan waktu untuk penelitian artikel ini.

\section{REFERENSI}

Apriani, A., Buyung, B., \& Relawati, R. (2017). Pengembangan Lembar Kerja Siswa (LKS) Berbasis Contextual Teaching And Learning (CTL) pada Materi Faktorisasi Suku Aljabar Kelas VIII SMP Negeri 9 Muaro PHI: Jurnal Pendidikan, l(1). Retrieved from http://phi.unbari.ac.id/index.php/phi/article/view/7

Bariyyah, K., \& Latifah, L. (2019). Kecerdasan Emosi Siswa Ditinjau dari Jenis Kelamin dan Jenjang Kelas. JPGI (Jurnal Penelitian Guru Indonesia), 4(2), 68. https://doi.org/10.29210/02379jpgi0005

Betyka, F., Putra, A., \& Erita, S. (2019). Pengembangan Lembar Aktivitas Siswa Berbasis Penemuan Terbimbing pada Materi Segitiga. JURING (Journal for Research in Mathematics Learning), 2(2), 179. https://doi.org/10.24014/juring.v2i2.7684

Chamundeswari, D. S. (2013). Emotional Intelligence and Academic Achievement among Students at the Higher Secondary Level. International Journal of Academic Research in Economics and Management Sciences, 2(4). https://doi.org/10.6007/ijarems/v2-i4/126 
Dewi, S. Z., \& Ibrahim, T. (2019). Pentingnya pemahaman konsep untuk mengatasi miskonsepsi dalam materi belajar IPA di sekolah dasar. Jurnal Pendidikan Universitas Garut, 13(1), 26-31. Retrieved from https://journal.uniga.ac.id/index.php/JP/article/view/823

Farhan, M., \& Alfin, E. (2019). The Effect of Emotional Intelligence and Self Effycacy Towards Students

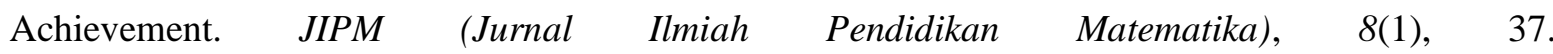
https://doi.org/10.25273/jipm.v8i1.4669

Febriyanti, R., \& Novitasari, N. (2019). POLA PEMECAHAN MASALAH MATEMATIKA PADA

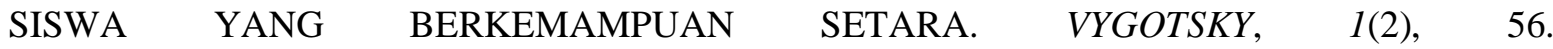
https://doi.org/10.30736/vj.v1i2.126

Handayani, T., Hartatiana, \& Muslimahayati. (2020). Analisis Kesalahan Siswa Dalam Menyelesaikan Soal Cerita Materi Barisan Dan Deret Aritmatika. Jurnal Pendidikan Matematika, 4(2020), 160-168.

Herutomo, R. (2017). Miskonsepsi Aljabar: Konteks Pembelajaran Matematika Pada Siswa Kelas Viii Smp. Jurnal Pendidikan Dasar, 1(November), 1-8. https://doi.org/10.36709/jobpgsd.v1i1.5135

Islami, A., Putra, A., Deswita, R., \& Rusliah, N. (2020). the Effect of Emotional Intelligence on Mathematical Concepts Understanding of Junior High School Students. MaPan, 8(1), 61. https://doi.org/10.24252/mapan.2020v8n1a5

Kamarullah, K. (2017). Pendidikan Matematika Di Sekolah Kita. Al Khawarizmi: Jurnal Pendidikan Dan Pembelajaran Matematika, 1(1), 21. https://doi.org/10.22373/jppm.v1i1.1729

Kristanti, D. (2020). Scaffolding Sebagai Upaya Mengatasi Kesalahan Matematika Siswa Kelas VIII di SMP Negeri 5 Meureubo. Vygotsky, 2(1), 54. https://doi.org/10.30736/vj.v2i1.193

Kurniawan, E., Mulyati, S., \& Rahardjo, S. (2017). Proses Asimilasi Dan Akomodasi Dalam. Jurnal Pendidikan : Teori, Penelitian Dan Pengembengan, 2(5), 592-598.

Labby, S., Lunenburg, F. C., \& Slate, J. R. (2012). Emotional Intelligence and Academic Success : A Conceptual Analysis for Educational Leaders. International Journal of Educational Leadership Preparation, 7 (1), 1-11.

Laurens, T., Batlolona, F. A., Batlolona, J. R., \& Leasa, M. (2018). How does realistic mathematics education (RME) improve students' mathematics cognitive achievement? Eurasia Journal of Mathematics, Science and Technology Education, 14(2), 569-578. https://doi.org/10.12973/ejmste/76959

Lestari, L., \& Surya, E. (2017). The Effectiveness of Realistic Mathematics Education Approach on Ability of Students' Mathematical Concept Understanding. International Journal of Sciences: Basic and Applied Research (IJSBAR), 34(1), 91-100. Retrieved from http://digilib.unimed.ac.id/id/eprint/24801

Limardani, G., Trapsilasiwi, D., \& Fatahillah, A. (2015). Analisis Kesulitan Siswa dalam Menyelesaikan Soal Operasi Aljabar pada Siswa Kelas VIII D SMP Negeri 4 Jember. Artikel Ilmiah Mahasiswa, 1(1), $1-7$.

Marhaeni, N. (2016). Hubungan Kecerdasan Emosi dengan Prestasi Belajar Matematika Siswa Kelas V 
Sekolah Dasar Segugus 1 Kecamatan Wates Kabupaten Kulon Progo Tahun Ajaran 2015/2016. Jurnal Pendidikan Guru Sekolah Dasar, 4, 334-343.

Masitoh, I., \& Prabawanto, S. (2016). Peningkatan Pemahaman Konsep Matematika dan Kemampuan Berfikir Kritis Matematis Siswa Kelas V Sekolah Dasar Melalui Pembelajaran Eksloratif. \begin{tabular}{l|llll} 
EduHumaniora | Jurnal Pendidikan Dasar Kampus Cibiru, & $7(2)$, & 186.
\end{tabular} https://doi.org/10.17509/eh.v7i2.2709

Nadeak, T. E. Y. (2020). Pengaruh Kecerdasan Emosional dan Sikap Siswa terhadap Pemahaman Konsep Kimia. SAP (Susunan Artikel Pendidikan), 5(2), 169-176. https://doi.org/10.30998/sap.v5i2.7697

Pangastuti, L., Johan, A., \& Kurniasari, I. (2014). Profil Kemampuan Komunikasi Matematika Siswa SMP Ditinjau Dari Kecerdasan Emosional. Jurnal Ilmiah Pendidikan Matematika, 3(2).

Planinic, M., Milin-Sipus, Z., Katic, H., Susac, A., \& Ivanjek, L. (2012). Comparison of student understanding of line graph slope in physics and mathematics. International Journal of Science and Mathematics Education, 10(6), 1393-1414. https://doi.org/10.1007/s10763-012-9344-1

Prayitno, S. H., Suwarsono, S., \& Siswono, T. Y. E. (2018). The profile of conceptual comprehension of pre-service teacher in the mathematical problem solving with low emotional intelligence. Journal of Physics: Conference Series, 983(1). https://doi.org/10.1088/1742-6596/983/1/012089

Singh, T., Verma, M. K., \& Singh, R. (2013). Role of Emotional Intelligence in Academic Achievement. I(2), 255-263. https://doi.org/10.4018/978-1-4666-4530-1.ch016

Suratman, D. (2011). Pemahaman Konseptual dan Pengetahuan Prosedural Materi Pertidaksamaan Linear Satu Variabel Siswa kelas VII SMK. Jurnal Cakrawala Kependidikan, 13. Retrieved from http://www.macalester.edu/geology/wirth/CourseMaterials.html

Zebua, V. (2020). Analisis Kesalahan Siswa Dalam Menyelesaikan Soal Barisan Dan Deret Ditinjau Dari Kemampuan Pemahaman Konsep Matematis. Jurnal LEMMA, 6(2), 122-133. https://doi.org/10.22202/j1.2020.v6i2.4088

Zhao, F. F., \& Schuchardt, A. (2021). Development of the Sci-math Sensemaking Framework: categorizing sensemaking of mathematical equations in science. International Journal of STEM Education, 8(1). https://doi.org/10.1186/s40594-020-00264-x. 